\title{
POSSIBILITIES OF FOREIGN EXPERIENCE IN CREDITING OF AGRICULTURAL ENTERPRISES IN UKRAINE
}

\author{
Mariana NAZAR ${ }^{1}$, Volodymyr KOVALIV ${ }^{2}$ \\ Lviv National Agrarian University, Ukraine
}

\begin{abstract}
The purpose of this article is to analyze existing systems of agricultural enterprises crediting in developed countries, as well as identify opportunities for the application of international experience in economic practice of Ukraine. The subject of research is models of farms crediting in developed countries. The methodology of this study is based on the use of methods of theoretical generalization, comparison and systematic approach towards the development of proposals of the usage of foreign experience in Ukrainian reality. Results. Experience in developed countries strongly suggests that the development of agricultural sector is not possible without effective public policy. Efficient crediting system of farms should include cooperative, commercial, specialized banks etc. Proper infrastructure of crediting institutions should be established. However, there are no structured creditors in Ukrainian agricultural crediting system and commercial banks credit agricultural enterprises in efficiently. The system of agricultural sector crediting is over centralized as well as dependent on funds allocated by state budget. It is possible to solve this problem by creation of regional crediting unions of agricultural enterprises based on the European model. Practical meaning. Taking into consideration the experience of developed countries, it is obvious that in a growing economic crisis, with the emergence and increasing competition in the agricultural market in order to form national agricultural sector co-operative banks should be founded. Thus, so far, it is neglected. Actuality. The relevance of this study is to identify ways to improve state support of agricultural enterprises and further improvement of the legal framework related to the functioning of agricultural sector crediting system based on the experience of foreign countries.
\end{abstract}

Key words: crediting, financial support, credit, agricultural enterprises, bank crediting.

JEL Classification: G21, G28, O24, Q14

\section{Introduction}

Effective use of agricultural potential of Ukraine is hampered by a lack of financial resources in the farm. However, their crediting is a key component of sustainable economic development and food security insurance. The problem of agricultural enterprises financing is caused by the specificity of the industry: deficit of free financial resources, low capital productivity, seasonality of production, and the production cycle, which depends on climatic conditions. All this makes the sector unattractive for crediting.

Agricultural enterprises pay special attention to finding funding sources, which are required for continuous operation and further development of the industry.

So, the question of bank crediting of agricultural enterprises is rather crucial as well as crediting by nonbanking financial institutions, which are considered to be the main funding institutions worldwide.

Thus, the purpose of the article is to research areas and funding mechanisms of solving the problems of agricultural enterprises based on international experience.

\section{Presenting of the main material}

Agricultural policy of most of the countries is aimed at supporting agricultural producers through subsidies, grants, benefits. Let us concentrate more on systems of financing of agricultural enterprises in Western Europe and the United States, which has its own specificity.

For example, in the UK there wasn't any specialized system of agricultural crediting; farmers were supported by government subsidies. Agricultural crediting is not the subject to state regulation, but that does not mean that commercial banks do not participate in agricultural sector crediting Midlend National bank deserve particular attention. It includes the financial management of agricultural department. In that department each manager works directly with clientfarmer, estimates his credit history, level of enterprise management, studies all the parameters funds movement, which enables the evaluation of the real needs of customers concerning financial costs (Official site Midland National Bank)

\footnotetext{
Corresponding author:

${ }^{1}$ Department of Management named after E. Khraplyvyi, Lviv National Agrarian University.

E-mail: mbilozir@mail.ru

${ }^{2}$ Department of Management named after E. Khraplyvyi, Lviv National Agrarian University.

E-mail : volodymyrk@mail.ru
} 
Nowadays, secured credits on land are widespread. The abovementioned credits are given by the Agricultural Mortgage Corporation. Among other sources of long-term crediting of the agricultural sector an English melioration company can be mentioned, as well as private loans related to life insurance policies (Yudin, 1992).

Farmers in the UK often use bank overdrafts instead of bank loans. Their main advantage is that the percentage is calculated from the amount provided as a one-day loan. Once paid the check at the bank, the loan amount decreases, interest on overdraft are added and should be paid quarterly.

In 1955 Agricultural Credit Corporation in the UK was established to guarantee return of farm credits, which guaranteed receiving bank overdrafts to farmers. Those overdrafts were directed for the reconstruction of farms to improve the efficiency and profitability of the agricultural sector. But the share of government subsidies in the value of agricultural production equals more than one-quarter and is nearly the highest in the world (Bodak, 2012).

Unlike in the UK, in Germany, Belgium, France, Denmark, the US historical development of the agricultural sector has led to the creation of specialized institutions for agricultural enterprises lending.

In France, kinds of loans, which are reimbursed in case of successful enterprise development, are very widespread, as well as loans with preferential interest. The leading role in farm crediting plays Credit Agricol, which is one of the largest banks in Europe, it serves over $75 \%$ of the credit needs of the agricultural sector in France. According to official statistics, 9 out of 10 French farms are clients of the bank (Official site Credit Agricole Bank).

Program of German agriculture crediting aims to support investment measures to rationalize and improve the living conditions of agricultural producers, improve product quality, and to introduce high-tech industries (The experience of state regulation and support of agriculture abroad).

In Canada, a leader in lending of the agricultural sector is the State Farm Credit Corporation (Farm Credit Corporation) established in 1959. The Corporation provides credit on the full range of tangible and intangible costs, acquisition of additional land, construction and modernization of facilities, purchase necessary equipment and animals, providing fertilizers, seeds purchase, payment of debt and others objectives. Term of the loan payment, which is provided by the corporation, amounts from 10 to 30 years. The size of the credit depends on the economic situation of the borrower (Nahornyi, 1998).

Activities of other credit institutions that operate in the market of loans for the agricultural sector are strictly regulated by the Ministry of Agriculture of Canada.

Thus, the activity of credit facility in the system of agrarian relations in Canada is regulated and coordinated by the state and aimed at development of efficient production.

The most developed system of specialized concessional crediting exists in the US, where 12 federal land banks were founded back in 1912, which are subordinate to the Council on agricultural crediting by the Ministry of Finance. These banks are also privileged because they are not subject to any local or federal taxes.

Lenders provide ample opportunity to the agricultural producers to choose sources of credit depending on the type and condition of the loan and the borrower. For financial services farmers set up special agencies: Forest service of farmers, farmers' guarantee funds, and Commodity Credit Corporation. There are also commercial and cooperative banks, other specialized agencies that deal with financial services of local agricultural producers.

According to Y. Luzan (Luzan, 2005), in the US these institutions provide the program of commercial lending of future harvest defined by the US Congress due to an appropriate range of crops. They also organize purchase of main types of food products surplus directly from manufacturers, as well as provide special farm loans for their development and agricultural insurance support. Abovementioned institutions also provide low-interest loans to support production of strategic agricultural products with credit repayment in the form of goods etc.

Farmers who participate in certain programs of the US Congress are granted with annually approved state guaranteed prices for agricultural products. In addition, after relevant contracts signed, farmers get the opportunity to obtain interest-free loan of non-profit and $50 \%$ of the total future production. There are also some government programs to support exports of agricultural products and foodstuffs (Luzan, 2005). In our opinion, on conditions of limited funding, in order to support domestic agricultural enterprises, the experience of credit guarantees programs should be taken into consideration as they were particularly effective in the United States.

Efficiency of agricultural sector crediting in the European Union is based on the following principles:

- it is a system of agricultural service cooperatives that allow agricultural producers to reject the services of intermediaries. The producers are owners and customers at the same time for them

- it is a multilevel system of agricultural crediting cooperation. At the local level these are credit cooperative organizations (rural cooperative fund, credit unions, etc.). At the regional level, they are united in local and regional banks, and they, in turn, create a central national level cooperative financial institutions - central cooperative bank. Such cooperative financial and crediting system of financial cooperation is the financial basis for the agricultural sector in a market economy and gives a possibility to provide affordable loans and other financial services for farmers (Honcharenko, 2006).

Agriculture of Central and Eastern Europe during the transformation of the economic system faced with many new issues: privatization, reform of land ownership and trade, stabilization of prices etc. The consequence of privatization was the creation of a great amount of new agricultural enterprises, which experienced lack of 
resources for economic activity in new conditions. In most countries with the economy in transition lending of the agricultural sector in 1990 was carried out on a cooperative basis with the participation of the state in crediting process.

In Slovakia state implements financial support of agricultural enterprises through credit leverage with the help of the State Fund for Agriculture and Food, which focuses on providing loans at low interest rates (3-5\%). It cooperates with the Agricultural Bank, which in turn provides economic analysis of credit conclusions granted to the Fund, and the business plan in terms of the possibility of credit repayment. Projects valued by bank according to the economic criteria are returned to the Fund, which makes the final decision on the loan. It should be noted that the demand for such loans exceeds the supply.

Slovak Bank of guarantee provides with agricultural crediting. In addition, the bank provides a limited amount of subsidies. Loan guarantees concern working capital loans given by commercial banks. Guaranteed loans are provided at the lower rate compared to non-guaranteed due to the lower risks for bank (Chrastinova, 1999).

Czech model of crediting support of agriculture is formed gradually. At the beginning of reformation this sphere was maintained by direct subsidies. In 1992 publicinterest long-term loans were introduced, but a year later, to strengthen the effectiveness of the credit industry support the State Guarantee Fund for agriculture and forestry was established. The Fund receives costs annually from the budget and in addition from the financial market. Its help lays in interest payments to banks and providing of credit guarantees under many programs. Additionally, the Fund provides interest-free loans (10-20 years) to farms in regions affected by floods (Silar, 1999).

In Hungary it was decided to provide credit support to farmers by creating special institutions different from the abovementioned. Agricultural crediting guarantee fund, established in 1991, is the first organization in the country that specializes in credit guarantees. The purpose of the Fund is to provide SMEs better access to credits and increase their credits reliability. The fund provides guarantees to SMEs, which take medium and long-term loans from financial institutions that are members of the Fund or cooperate with it (Danilovska, 2005).

In Poland, the system of cooperative banks provides loans for $90 \%$ of production, marketing and processing of agricultural products. Farm crediting system in Poland now resembles a credit system of Western countries and consists of three levels: the Central Bank of Credit Unions; 9 regional banks; 1,200 local cooperative banks.

In agricultural credit policy of Poland considerable place is given to the modernization and rationalization of the agrarian structure, consolidation of young farmers in the countryside, aid to agriculture in areas with conditions unfavourable for agriculture. State regulation in this area is implemented with the support of the Agency for restructuring and modernization of agriculture. The scope of the Agency mainly includes loans, development projects and agricultural processing companies (more than $1 / 3$ credits); purchase of machinery and equipment to improve productivity and product quality (20\%); purchase products produced by agricultural enterprises (43\%) (Danilovska, 2005).

Some ways of problem solutions of farms crediting in these countries, though significantly different among themselves (which shows the flexibility and great potential credit as a tool for intervention) may be used today in Ukraine. Although there are three parties in each of these states, roles and responsibilities of each differ substantially. Especially differ positions of the bank in the system: in each country, its role in the evaluation of offers is leading, but the responsibility of participation in risk is different.

Thus, experience of Poland may be useful in terms of basic principles of providing payments to interest on loans (the system is definitely more effective than national) if to talk about the possibilities of borrowing of governmental crediting support techniques in the sphere of agriculture. An example of Slovakia in terms of low-interest loans is not feasible to be introduced in Ukraine, because commercial banks will not agree to reduce interest rates substantially, and the state does not possess enough levers of influence for them.

World practice shows that the credit system of agricultural enterprises should combine government support specific mechanisms for the protection of bank loans, maintenance of various financial intermediaries, especially cooperative and specialized (agricultural) banks that are essentially different in terms of their functions and terms of providing support and crediting. The experience of developed countries shows that in a growing economic crisis, with the emergence and increased competition in the agricultural market for the modern formation of national agricultural sector agricultural cooperative banks should play an extremely positive role. Nowadays the establishment of the banks in Ukraine is neglected.

\section{Findings}

In our opinion, from the foregoing items stabilization, development and innovation should be allocated. Particularly, it is essential to select the elements that will enable direct impact on the current state of Ukraine's economy, where the main problems are generated. We believe that the main problem lays in the lack of available resources, which is cheaper and in sufficient quantity. In recent years it was proved that the banking system is not able to ensure the development of the credit market. We, therefore, suggest to use the Polish experience in financial support, due to the fact that it has developed strategy and created a number of agencies and foundations that deal with co-financing enterprises since the independence was proclaimed. Thus, there were following steps towards stabilization of the situation in Poland:

- Deregulation of prices on agricultural products;

- Abolition of subsidies on consumption and capital goods; 
- Stabilization of the currency;

- Introduction of real interest rates;

- Beginning of privatization process;

- Exposition of the domestic market to more foreign competition.

Funds and agencies with a target orientation played an important role in the stabilization and innovative development of agricultural enterprises. In 1992 the Fund of Agriculture Restructuring and Debt Relief was founded, whose main field of work was the issuance of credits associated with the liquidation of unfavourable production conditions (drought, floods, etc.). The Agency of Restructuring and Modernisation of Agriculture was set up in 1993. It deals with additional payments to credit interest data by banks that cooperate with it; provides credit guarantees and sureties for bank loans; financing / co-financing of activities related to upgrading of rural infrastructure, which presupposes target elevation, change of qualifications of professional farmers (Podstavka, 2000).

At the beginning of competitive agriculture, creation of the Agency of Restructuring and Modernisation of Agriculture has funded 33 credit lines, in 1996, there were 21 lines, and after 1998 only 8 lines remained and they obtain the following character:

1. Implementation of investment projects in agriculture and its services.

2. Purchase of land.

3. Opening or creation of farms by people under 40 who have worked at least for 3 years in agricultural sphere or with qualification connected with agriculture.

4. Investment measures under sectoral programs.

5. Credit for working capital.

6. Creation of new jobs.
7. Elimination of consequences of natural disasters.

8. Buying up and storage of agricultural goods.

One of the biggest problems today is the discrepancy of interest rates and capabilities of enterprises. Producers are not able to pay $40-60 \%$ per annum for short-term loans, which may be a subject to insurance. Certainly the percentage affects inflation but, in our opinion, right measures of NABU are able to reduce interest rates through the discount rate, targeted credit auctions etc. Taking into consideration foreign experience it can be claimed that reasonable rate for agricultural business is 3-5\% per annum, preferential loans are carried out at $1-2.5 \%$. This situation creates difficult conditions for Ukrainian enterprises in the light of Ukraine's accession to the EU.

\section{Conclusions}

Due to international experience, we consider that the state must continue provide crediting support to agricultural producers. If mechanism of crediting at lower rates will remain, the amount of partial compensation of interest rates should be fixed and not dependant on bank lending rates. Compensation for investment lending programs should be more sufficient than the short-term crediting to replenish working capital. State interest towards directions of the agricultural sector should be prior while selecting companies to participate in the programs of concessional lending. We consider it appropriate to support agricultural producers from budget, both by loans of commercial banks and credit unions. In order to provide crediting of agricultural enterprises in crisis, the government should support the establishment of crediting cooperatives in rural areas through the proceedings of special lending programs.

\section{References:}

Yudin, A. (1992). State regulation of lending and agriculture in the UK and US. International Agricultural Journal, 5: 44-50.

Bodak, H.I. (2012). Foreign experience of agricultural production. Scientific Bulletin of National Forestry University, 22.6: 164-169.

Official site Midland National Bank. Retrieved from: http://www.midlandnb.com/2706/mirror/.

Official site Credit Agricole Bank. Retrieved from: http://www.credit-agricole.fr/agriculteur.

The experience of state regulation and support of agriculture abroad. Russian agrarian portal "agricultural education". Retrieved from: http://www.agroobzor/econ/a-125

Nahornyi, V.D. (1998). The structure, functions and budget of the Ministry of Agriculture and Food Canada. Scientific and technological agriculture, 3: 44.

Luzan , Y.A. (2005). Financial aspects of the market environment in the agricultural sector. Accounting and Finance, 6: 5-13.

Honcharenko, V. (2006). Credit co-operatives, build new rural financial infrastructure. "Mirror of the Week".

Chrastinova, H. (1999). Finansing of the Agricultural Sector of Slovak Republic and Credit infrastructure in Transition Economies. OECD Proceedins. OECD centre for co-operation with Non- Member, 358-364.

Silar, S. (1999). Credit Support and the Guarantee Fund for Fermers and Foresty in Czech Republic. Agricultural Finance and Credit infrastructure in Transition Economies. OECD centre for co-operation with Non- Member, 263-276.

Danilovska, A. (2005). Support for lending in Poland compared to other countries. Association of agricultural economists and agribusiness. Annals of Science, V.6: 66-70.

Podstavka, M. (2000). Financial system of agriculture on the background of Polish integration into the European Union.FAPA, 79-86. 


\section{Марьяна НАЗАР, Владимир КОВАЛИВ \\ ВОЗМОЖНОСТИ ЗАРУБЕЖНОГО ОПЫТА В КРЕДИТОВАНИИ СЕЛЬСКОХОЗЯЙСТВЕННЫХ ПРЕДПРИЯТИЙ В УКРАИНЕ}

Аннотация. Целью данной статьи является анализ действующих систем кредитования сельскохозяйственных предприятий в развитых странах мира, а также выявление возможностей применения зарубежного опыта в экономической практике Украины. Предметом исследования являются модели кредитования сельскохозяйственных предприятий в развитых странах мира. Методика данного исследования базируется на использовании методов теоретического обобщения, сравнения, а также системный подход для разработки предложений по применению зарубежного опыта в украинских реалиях. Результаты. Опыт развитых стран убедительно свидетельствует, что развитие аграрного сектора экономики невозможно без эффективной государственной политики. Результативная система кредитования сельскохозяйственных предприятий должна включать кооперативные, коммерческие в.т.ч. специализированные банки и тому подобное. Должна быть соответственно сформирована инфраструктура кредитных институтов. Однако, в Украине система агрокредитования не имеет сейчас структурированного кредитора, а коммерческие банки неэффективно кредитуют сельскохозяйственные предприятия. Система кредитования аграрной сферы является чрезмерно централизованная и зависит от средств, выделяемых государственными бюджетами. Решить данную проблему можно созданием по европейскому образцу региональных кредитных союзов аграрных предприятий. Практическое значение. Изучение опыта развитых стран показывает, что в условиях роста экономического кризиса, с возникновением и обострением конкуренции на аграрном рынке для современного становления отечественного аграрного сектора экономики исключительно положительную роль должны сыграть сельскохозяйственные кооперативные банки, созданию которых в Украине уделяется недостаточно внимания. Значение/оригинальность. Актуальность данного исследования заключается в выявлении путей для улучшения государственной поддержки сельскохозяйственных предприятий и дальнейшем совершенствовании нормативно-правовой базы, связанной с функционированием системы кредитования аграрного сектора на основе применения опыта зарубежных стран. 